\title{
EL AGUJERO
}

\section{Gema Santamaría}

abro un agujero con mi lengua.

un agujero por donde puedan mis piernas patalear

hasta encontrar el agua tibia de algún pozo.

niña. agrietada. vestida de blanco.

olvidó su nombre y no puede ahora regresar a casa.

casa-casita de muñecas, de vestidos morados y encajes celestes, muñecas santas, de ojos abiertos -nunca lloran, nunca sueñan. alguien. ¿me escucha? un cuchillo es inocente, el diablo es la herida, la herida que se busca y se corteja la sangre deseada para darle al dolor una sustancia.

alguien. una lámpara. pero no más luces amarillas en mi cuarto. no más fotos debajo de las mesas, no más señas en la orilla de los libros.

no logro iluminarme. me persigue esta amoratada tristeza. tengo las rodillas rotas. me tropiezo, me trapecio, trapecista. luego la náusea, luego el espanto, luego, de nuevo, el vértigo. alguien. esta casa se derrumba. tiene grietas por todas partes. se le pudren las ventanas y las puertas. está hinchada por la lluvia, ¡estás gorda casa vieja!

alguien. un agujero. por favor, por alguna parte.

escapa, niña, escapista. pero si te entumes, si te apagas, si hay un moño negro regalando muerte en la entrada de tu casa. shhhh. duerme. duerme. cava. cava.

saca la lengua, lechosa y ácida.

siempre el pozo estuvo ahí.

temblando

en un vaso de agua. 